\title{
Screening Inherited Metabolic Disorder in Children with Intellectual Disability and Epilepsy
}

\author{
Zeka Geriliği ve Epilepsisi Olan Çocuklarda Kalıtsal Metabolik Hastalık Taraması
}

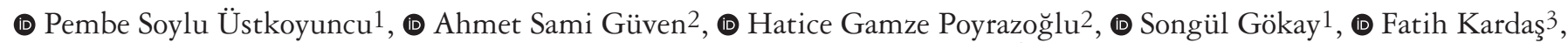 \\ (1) Mustafa Kendirci3 3 , (1) İkbal Gökçek ${ }^{4}$, (1) Yasemin Altuner Torun ${ }^{4}$ \\ 1 University of Health Sciences, Kayseri Training and Research Hospital, Clinic of Pediatric Nutrition and Metabolism, Kayseri, Turkey \\ 2University of Health Sciences, Kayseri Training and Research Hospital, Clinic of Pediatric Neurology, Kayseri, Turkey \\ ${ }^{3}$ Erciyes University Faculty of Medicine, Department of Pediatrics, Division of Pediatric Nutrition and Metabolism, Kayseri, Turkey \\ 4University of Health Sciences, Kayseri Training and Research Hospital, Clinic of Pediatrics, Kayseri, Turkey
}

\begin{abstract}
Objective: To indicate the benefits of the screening of inherited metabolic disorders in patients with epilepsy, global developmental delay, and intellectual disability.

Materials and Methods: The medical records of 1100 patients who were investigated for inherited metabolic disorders between March 2014 and June 2017 were evaluated. Five hundred patients with epilepsy and global developmental delay/intellectual disability with mild/moderate and non-specific neurologic findings were enrolled in the study.

Results: Inherited metabolic disorders were detected in 7 of 500 patients (1.4\%) with epilepsy and global developmental delay/intellectual disability. One patient was diagnosed as having tyrosinemia type-2, one had Menkes disease, one had mitochondrial disease, one had hyperphenylalaninemia, two siblings were diagnosed as having 3-methylcrotonyl Coa carboxylase deficiency, and one patient was diagnosed as having phenylketonuria.

Conclusion: The prevalence of inherited metabolic disorders is higher in countries with a high consanguinity ratio such as Turkey. Lack of the regular screening in patients with mild/moderate and non-specific neurologic findings result in late diagnosis.
\end{abstract}

Keywords: Inherited metabolic disorder, epilepsy, intellectual disability, metabolic screening

$\ddot{\mathbf{O z}}$

Amaç: Bu çalışmanın amacı epilepsi, yaygın gelişimsel gecikme ve zeka geriliği olan hastalarda kalıtsal metabolik hastalık taraması yapmanın yararlarını göstermektir.

Gereç ve Yöntem: Mart 2014 ve Haziran 2017 arasında kalıtsal metabolik hastalık nedeniyle araştırılan 1100 hastanın tıbbi kayıtları değerlendirildi. Çalışmaya hafif/orta ve non-spesifik nörolojik bulgusu olan 500 epilepsi ve yaygın gelişimsel gecikme/zeka geriliği olan hasta alındı.

Bulgular: Epilepsi ve yaygın gelişimsel gecikme/zeka geriliği olan 500 hastanın 7'sinde (\%1,4) kalıtsal metabolik hastalık tespit edildi. Bir hastaya tirozinemi tip-2, bir hastaya Menkes hastalığı; bir hastaya mitokondriyal hastalık, bir hastaya hiperfenilalaninemi, 2 kardeşe 3-metilkrotonil CoA karboksilaz eksikliği ve bir hastaya da fenilketonüri tanısı konuldu.

Sonuç: Türkiye gibi yüksek akrabalık oranına sahip ülkelerde kalıtsal metabolik hastalık prevalansı daha yüksektir. Hafif/orta ve non-spesifik nörolojik bulguları olan hastalarda düzenli bir taramanın olmaması geç tanı ile sonuçlanır.

Anahtar Kelimeler: Kalıtsal metabolik hastalık, epilepsi, zeka geriliği, metabolik tarama

Address for Correspondence/Yazışma Adresi: Pembe Soylu Üstkoyuncu MD, University of Health Sciences, Kayseri Training and Research Hospital, Clinic of Pediatric Nutrition and Metabolism, Kayseri, Turkey

Phone: +90 5056716471 E-mail: drpembesoylu@erciyes.edu.tr ORCID: orcid.org/0000-0001-9867-1280

Received/Geliş Tarihi: 13.09.2018 Accepted/Kabul Tarihi: 14.02.2019

${ }^{\circ}$ Copyright 2019 by Turkish Neurological Society

Turkish Journal of Neurology published by Galenos Publishing House. 


\section{Introduction}

Inherited metabolic disorders (IMDs) are not common causes of epilepsy and intellectual disability (ID). IMDs should be considered in the presence of neonatal seizures, neonatal or infantile deaths with unknown etiology, affected family members, parental consanguinity, macrocephaly or microcephaly, hydrops fetalis, progressive global psychomotor retardation, multisystem involvement such as cardiomyopathy, hepatosplenomegaly, cataract and muscle weakness, and characteristic magnetic resonance imaging findings such as cerebral and/or cerebellar atrophy, abnormal myelination and striatal necrosis $(1,2,3,4)$. Seizures may be a part of a more complex neurologic presentation or sometimes only a feature of IMDs. Some IMDs (40-60\%) can lead to isolated or recurrent convulsions (3).

ID, which is also known as mental retardation, is characterized by impairment of cognitive functions, adaptive behavior and life skills with limitations of learning, and presentation before age 18 years. In addition, children younger than 6 years are considered to have global developmental delay (GDD) if they perform more than 2 SDS below age-matched peers. GDD affects $1-3 \%$ of children aged under 6 years, and there are $2-3 \%$ of patients with ID in different populations $(5,6)$. Global psychomotor retardation without other potential explanations may be suggestive of an IMD. In the absence of clues for other common causes of GDD/ ID, the study of metabolic tests is recommended. Focused or sequential metabolic testing can increase the diagnostic rates up to $14 \%(7)$.

Treatments of some IMDs include dietary therapy, essential amino acid and vitamin supplementation, substrate inhibition and reduction therapy, enzyme replacement therapy, hematopoietic stem cell transplantation, and gene therapy. Therefore, early recognition is very important. In addition, identification of non-treatable causes is beneficial to the individual's family and allows genetic counseling (8).

The aim of this study was to explore the benefits of screening for IMDs in patients with epilepsy and GDD/ID with mild/ moderate and non-specific neurologic findings.

\section{Materials and Methods}

This was a retrospective single-center clinical study. The medical records of 1100 patients who were investigated for IMDs between March 2014 and June 2017 were evaluated. Detailed disease histories, age, sex, and physical examinations were recorded in a form.

Inclusion criteria: Five hundred patients with epilepsy and GDD/ID with mild/moderate and non-specific neurologic findings were enrolled in the study.

Exclusion criteria: Patients with a specific genetic syndrome or neurologic disease, central nervous system (CNS) infection or CNS tumor, and febrile convulsions were excluded from the study. Although multidrug-resistant convulsions, cerebral palsy, and infantile severe hypotonia indicate metabolic disorders, they were also excluded from the study because the aim of this study was to explore IMDs in epilepsy and GDD/ID with mild/moderate neurologic symptoms.
Laboratory investigations: Non-specific tests include complete blood count, electrolytes, glucose levels, liver transaminases, urea, creatinine, creatine phosphokinase, thyroid function tests, vitamin B12, serum ammonia, lactate, pyruvate levels and peripheral chromosome analysis. Specific metabolic tests consist of plasma and urine amino acid analysis, blood acyl carnitine analysis, biotinidase activity and urinary organic acid analysis. Urinary glycosaminoglycan levels, urine sulfide oxide, serum copper, ceruloplasmin and homocysteine levels were studied in selected cases. All molecular genetic analyses were performed using next-generation sequencing in patients diagnosed as having IMDs.

The study was approved by the Ethics Committee of Erciyes University, Medical Faculty (Protocol number: 2017/421).

Informed consent was given by all parents of children with IMDs.

Statistical Analysis

The IBM SPSS Statistics 24.0 statistical package program was used in the evaluation of the data. Parameters with abnormal distribution are expressed as median (25th percentile $75^{\text {th }}$ percentile). Data are presented as counts, percentages, and minimum and maximum values.

\section{Results}

Five hundred patients with epilepsy and GDD/ID whose physical examinations and metabolic investigations were complete, and who met the inclusion criteria of the study were enrolled. Among the 500 children, 293 were male and 207 were female. The sex ratio was $1.4 / 1$ in favor of the males. The ages of patients ranged from 20 days to 18 years. One hundred sixty-five patients $(33 \%)$ were evaluated for GDD/ID of unknown etiology. Two hundred sixty-eight patients $(53.6 \%)$ were followed up for epilepsy, and 67 patients (13.4\%) with epilepsy and GDD/ID. Three hundred three $(90.4 \%)$ of the 335 patients with epilepsy were using single antiepileptic drugs, 32 (9.6\%) were using two antiepileptic drugs. Denver Developmental Screening Test II records of 108 patients and intelligence tests of 84 patients were available. Intelligence quotient (IQ) of 50-70 was considered mild impairment, and an IQ of less than 50 was considered moderateto-severe impairment. The characteristics of children investigated for IMDs are shown in Table 1.

IMDs were diagnosed in seven patients as follows: one patient was diagnosed as having Tyrosinemia type-2, one had Menkes disease, one had Mitochondrial disease, one had Hyperphenylalaninemia, two siblings were diagnosed as having 3-methylcrotonyl CoA carboxylase deficiency, and one had Phenylketonuria. The demographic and clinical findings of patients with IMDs are shown in Table 2 and the laboratory findings and prognoses of patients with IMDs are shown in Table 3. In this study, the prevalence of IMDs among patients with epilepsy and GDD/ID was $1.4 \%$.

\section{Discussion}

Seizures may be a part of a more complex neurologic presentation or sometimes only feature as IMDs. MercimekMahmutoglu et al. (9) evaluated 150 patients who underwent 
lumbar puncture due to epilepsy and movement disorder. IMDs were diagnosed in $6(4 \%)$ of 150 patients. Sixty-six (44\%) of 150 patients had GDD and epilepsy. IMDs were found in $1 / 268(0.37 \%)$ of patients with epilepsy and 2/67 (2.98\%) of patients with epilepsy and GDD/ID in our study, similar to these findings.

ID is a heavy burden both on the individual and society because its effects continue for a lifetime and also patients with ID have increased morbidity and mortality (10). Therefore, it is very important to identify treatable IMDs. There are few studies regarding ID and IMDs. Treatable IMDs were identified in $1-5 \%$ of patients as the cause of ID in some reports $(11,12)$. Treatable IMDs, which have been detected in our study, are phenylketonuria, tyrosinemia type 2, mitochondrial disorders,

Table 1 . The characteristics of the children investigated for inherited metabolic disorders

\begin{tabular}{|lll|}
\hline & $\begin{array}{l}\text { Total number } \\
\text { of patients }\end{array}$ & $(\%)$ \\
Variables & 500 & 100 \\
Sex distribution & & \\
Male & 293 & 58.6 \\
Female & 207 & 41.4 \\
GDD/ID & 165 & 33 \\
Epilepsy & 268 & 53.6 \\
Epilepsy and GDD/ID & 67 & 13.4 \\
DDST II (n=108) & & \\
Language development & 19 & 17.60 \\
Gross motor development & 38 & 35.19 \\
Retardation in two areas & 12 & 11.11 \\
Retardation in three areas & 13 & 12.03 \\
Retardation in all areas & 26 & 24.07 \\
Intelligence test score (n=84) & & \\
Borderline intelligence & 7 & 8.33 \\
Mild mental retardation & 49 & 53.33 \\
Moderate mental retardation & 28 & \\
DDST II: Denver Developmental Screening Test II, GDD: Global developmental \\
delay, ID: Intellectual disability
\end{tabular}

3-methylcrotonyl CoA carboxylase deficiency, and Menkes disease.

Engbers et al. (13) evaluated 433 patients with neurodevelopmental disorders and showed that $3 \%$ of these patients had IMDs. IMDs were found in 4/165 (2.4\%) of patients with GDD/ID in our study.

Papavasiliou et al. (14) evaluated 118 patients with unexplained developmental delay ages from 3 months to 13 years and found $16(13.6 \%)$ patients with neurometabolic disorder. The higher rate of IMDs in this report was attributed to more specific testing being performed such as cerebrospinal fluid lactate, very long-chain fatty acids, and mitochondrial enzymes.

van Karnebeek and Stockler-Ipsiroglu (15) reported that nontargeting screening with plasma amino acids, total homocysteine, acyl carnitine profile, copper, ceruloplasmin, urine organic acid, purine and pyrimidines, creatine metabolites, oligosaccharides, and glycosaminoglycans identified $64 \%$ of treatable IMDs. Diagnosis of all our patients was performed using non-targeting screening. The blood acyl carnitine profile and amino acid analysis are very important in the first step of specific metabolic investigations, and $\mathrm{LC} / \mathrm{MS} / \mathrm{MS}$ analysis allows the diagnosis of a large number of IMDs alone.

Henderson et al. (16) screened 1087 patients with mental retardation and found phenylketonuria (PKU) in three patients, cystinuria in two patients, and Hartnup disease in one patient. The overall frequency of IMDs was found as $0.6 \%$. In our study, the frequency of IMDs among patients with epilepsy and GDD/ ID was $1.4 \%$.

PKU is a well-known cause of ID. Papassin et al. (17) reported PKU in a patient with ID at 20 years of age, like our case. The frequency of PKU was reported as 1/1581 in 4744 children with mental retardation (18). The PKU frequency was $1 / 165$ in patient with unexplained GDD/ID in our study.

The incidence of IMDs is remarkably high in the Turkish population, which is partially due to the high rate of consanguinity. A total of 572 cases with 12 different types of aminoacidopathies were detected in 10,800 Turkish children with ID (19). PKU $(4.7 \%)$ and homocysteinuria $(0.2 \%)$ were common causes of ID in this report. The detection of Hyperphenylalaninemia in one of seven patients diagnosed with IMD and the detection of PKU in one patient supports this study.

Table 2. The demographic and clinical findings of the patients with inherited metabolic disorders

\begin{tabular}{|c|c|c|c|c|}
\hline Case & Age & Sex & Consanguinity & Clinical findings \\
\hline 1 & 8 months & M & $(-)$ & Epilepsy, poor head control and hair changes \\
\hline 2 & 4 years & M & $(+)$ & $\begin{array}{l}\text { Complex partial seizure, mild ID in Stanford-Binet Intelligence Scale and } \\
\text { intermittent photophobia }\end{array}$ \\
\hline 3 & $\begin{array}{l}10 \text { years } 4 \\
\text { months }\end{array}$ & $\mathrm{F}$ & $(-)$ & $\begin{array}{l}\text { Headache, learning disability, attention deficit hyperactivity disorder (using } \\
\text { methylphenidate) and mild ID in WISC-R }\end{array}$ \\
\hline 4 & 9 years & M & $(+)$ & $\begin{array}{l}\text { Generalized tonic clonic seizures (using valproic acid) and mildly impaired } \\
\text { concentration difficulty in recent months. }\end{array}$ \\
\hline 5 & 17 years & M & $(+)$ & Poor school performance and mild ID in WISC-R \\
\hline 6 & 9 years 2 months & $\mathrm{F}$ & $(+)$ & Convulsion and mild ID in WISC-R \\
\hline 7 & 15 years & $\mathrm{M}$ & $(+)$ & Learning disability and mild ID in the WISC-R \\
\hline
\end{tabular}




\section{Table 3. The laboratory findings and prognosis of the patients with inherited metabolic disorders}

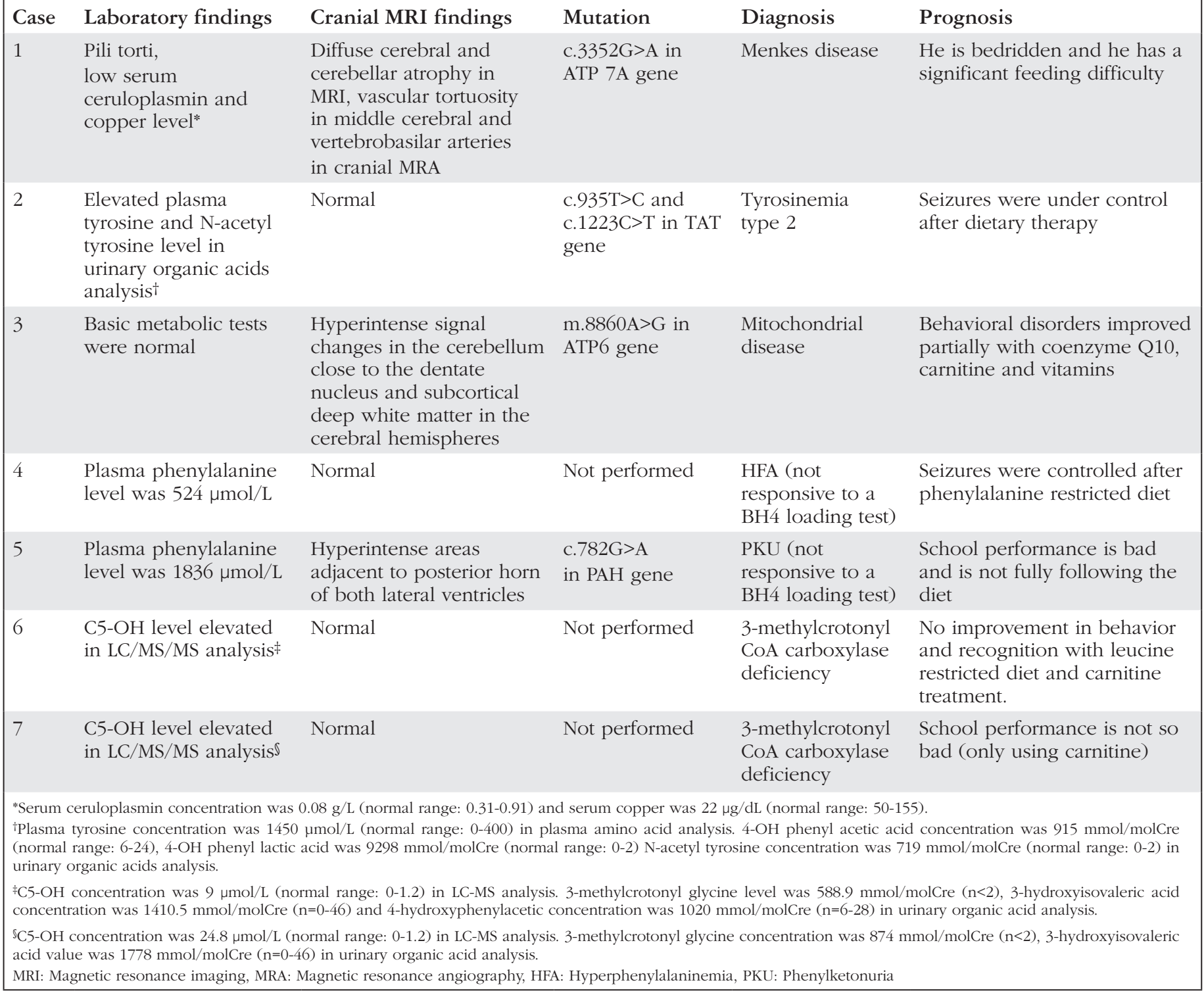

Sempere et al. (20) evaluated 944 patients with unexplained ID and reported three patients with cerebral creatine deficiency syndromes, one patient with adenylosuccinate lyase deficiency, and three patients with PKU.

\section{Study Limitations}

The limitation of this study is that it did not allow screening of creatine biosynthesis, gamma-aminobutyric acid catabolism, purine and pyrimidine metabolism, congenital glycosylation, and glucose transport defects, which can present with nonspecific ID.

\section{Conclusion}

Early diagnosis and treatment is very important, and also identification of non-treatable causes is beneficial to the affected individual's family and allows genetic counseling. The prevalence of IMDs is higher in countries with a high consanguinity ratio such as Turkey. The lack of regular screening in patients with mild/moderate and non-specific neurologic findings result in late diagnosis.

\section{Ethics}

Ethics Committee Approval: The study was approved by the Ethics Committee of Erciyes University, Medical Faculty, (Protocol number: 2017/421).

Informed Consent: Consent form was filled out by all parents of cases diagnosed with inherited metabolic disorders.

Peer-review: Internally peer-reviewed.

\section{Authorship Contributions}

Surgical and Medical Practices: P.S.Ü., A.S.G., H.G.P., Concept: P.S.Ü., Design: P.S.Ü., A.S.G., Y.A.T., Data Collection 
or Processing: H.G.P., İG., S.G., Analysis or Interpretation: M.K., F.K., Literature Search: P.S.Ü., İ.G., Writing: P.S.Ü.

Conflict of Interest: The authors declare that there are no conflicts of interest.

Financial Disclosure: The author declared that this study received no financial support.

\section{References}

1. Wolf NI, García-Cazorla A, Hoffmann GF. Epilepsy and inborn errors of metabolism in children. J Inherit Metab Dis 2009;32:609-617.

2. Dhamija R, Patterson MC, Wirrell EC. Epilepsy in Children--When Should We Thinek Neurometabolic Disease? J Child Neurol 2012;27:663667.

3. Campistol J, Plecko B. Treatable newborn and infant seizures due to inborn errors of metabolism. Epileptic Disord 2015;17:229-242.

4. Michelson DJ, Shevell MI, Sherr EH, Moeschler JB, Gropman AL, Ashwal S. Evidence report: Genetic and metabolic testing on children with global developmental delay: report of the Quality Standards Subcommittee of the American Academy of Neurology and the Praçctice Committee of the Child Neurology Society. Neurology 2011;77:1629-1635.

5. Petersen MC, Kube DA, Palmer FB. Classification of developmental delays. Semin Pediatr Neurol 1998;5:2-14.

6. van Karnebeek CD, Shevell M, Zschocke J, Moeschler JB, Stockler S. The metabolic evaluation of the child with an intellectual developmental disorder: Diagnostic algorithm for identification of treatable causes and new digital resource. Mol Genet Metab 2014:111:428-438.

7. García-Cazorla A, Wolf NI, Serrano M, et al. Mental retardation and inborn errors of metabolism. J Inherit Metab Dis 2009;32:597-608.

8. van Karnebeek CD, Stockler S. Treatable inborn errors of metabolism causing intellectual disability: a systematic literature review. Mol Genet Metab 2012;105:368-381.
9. Mercimek-Mahmutoglu S, Sidky S, Hyland K, et al. Prevalence of inherited neurotransmitter disorders in patients with movement disorders and epilepsy: a retrospective cohort study. Orphanet J Rare Dis 2015;10:12.

10. Daily DK, Ardinger HH, Holmes GE. Identification and evaluation of mental retardation. Am Fam Physician 2000;61:1059-1067.

11. van Karnebeek CD. Inborn errors of metabolism are not hopeless; early identification of treatable conditions in children with intellectual disability. Ned Tijdschr Geneeskd 2014;158:8042.

12. van Karnebeek CD, Jansweijer MC, Leenders AG, Offringa M, Hennekam RC. Diagnostic investigations in individuals with mental retardation: a systematic literature review of their usefulness. Eur J Hum Genet 2005;13:6-25.

13. Engbers HM, Berger R, van Hasselt P, et al. Yield of Additional Metabolic Studies in Neurodevelopmental Disorders. Ann Neurol 2008;64:212-217.

14. Papavasiliou AS, Bazigou H, Paraskevoulakos E, Kotsalis C. Neurometabolic Testing in Developmental Delay. J Child Neurol 2000;15:620-622.

15. van Karnebeek CD, Stockler-Ipsiroglu S. Early identification of treatable inborn errors of metabolism in children with intellectual disability: The Treatable Intellectual Disability Endeavor protocol in British Columbia. Paediatr Child Health 2014;19:469-471.

16. Henderson HE, Goodman R, Schram J, Diamond E, Daneel A. Biochemical screening for inherited metabolic disorders in the mentally retarded. S Afr Med J 1981;60:731-733.

17. Papassin J, Pierunek J, Corne C, Besson G. Phenylketonuria, an unusual diagnosis of mental retardation in an adult patient. Rev Neurol (Paris) 2015;171:739-740.

18. Wuu KD, Hsiao KJ, Chen CH, Hsiao TS, Chang CY, Chu YK. Screening for inherited metabolic diseases and congenital hypothyroidism in 4,744 mentally retarded school children in Taiwan. Jinrui Idengaku Zasshi 1988;33:33-40.

19. Ozalp I, Coskun T, Tokol S, Demircin G, Mönch E. Inherited metabolic disorders in Turkey. J Inherit Metab Dis 1990;13:732-738.

20. Sempere A, Arias A, Farré G, et al. Study of inborn errors of metabolism in urine from patients with unexplained mental retardation. J Inherit Metab Dis $2010 ; 33: 1-7$. 